\title{
Field Evaluation of Spinetoram 12 SC against Spodoptera litura Fabricius on Pigeonpea
}

\author{
Sanjeevi Kumar" and Muthukrishnan \\ Department of Agrl. Entomology, Tamil Nadu Agricultural University, \\ Coimbatore - 3, Tamil Nadu, India \\ *Corresponding author
}

\section{A B S T R A C T}

Keywords

Spinetoram,

Pigeonpea, Field

efficacy, Spodoptera

litura, Phytotoxicity

and Yield.

Article Info

Accepted:

20 September 2017

Available Online:

10 November 2017
Spodoptera litura (Noctuidae: Lepidoptera) is a notorious leaf damaging pest in Tamil Nadu in pigeonpea and responsible for considerable yield loss. A new biological insecticide spinetoram 12 SC was evaluated for effect on S. litura on pigeonpea at field conditions during 2012-2013 and 2013-2014 kharif seasons. Spinetoram $12 \mathrm{SC}$ was applied as foliar spray at 27,36 and $45 \mathrm{~g}$ a.i. $\mathrm{ha}^{-1}$ and compared with emamectin benzoate 5 SG @ $11 \mathrm{~g}$ a.i. ha ${ }^{-1}$, spinosad 45 SC @ $78 \mathrm{~g}$ a.i. ha ${ }^{-1}$ and monocrotophos 36 SL @ $500 \mathrm{~g}$ a.i. ha ${ }^{-1}$. Results indicated that spinetoram $12 \mathrm{SC}$ was significantly effective at 36 and $45 \mathrm{~g}$ a.i. ha $^{-1}$ when sprayed thrice at 15 days interval in minimizing larval population on pigeonpea plants and in increasing the grain yield. All the spinetoram doses did not show any phytotoxic symptoms on pigeonpea plants.

\section{Introduction}

India accounts for 90 per cent of the world production and pulses are consumed by a large population as a protein rich staple food. The country annually imports 3-4 lakh tonnes of pigeonpea to meet the domestic demand. Pigeonpea (Cajanus cajan L.) is an important pulse or grain legume crop in semi-arid tropical and subtropical areas of the world. India is the largest producer and consumer of pigeonpea in the world, India is producing 183.4 lakh tonnes of pulses from an area of 96.26 lakh hectares. Pigeonpea is grown in 85.22 lakh hectares with an annual production of 88.33 lakh tonnes with an average productivity of $1036.00 \mathrm{~kg} / \mathrm{ha}$. In Tamil Nadu, it is cultivated in an area of 0.071 lakh hectares with 0.045 lakh tonnes of production and with a productivity of $645 \mathrm{~kg} / \mathrm{ha}$ during 2012-13 (Anon., 2013). Major constraint in the production of pigeonpea is the damage caused by insect pests with avoidable losses extending up to 78 per cent. The pigeonpea attack of number of insect pests viz., Helicoverpa armigera (Hubner), Maruca vitrata (Geyer), Lampides boeticus (Linnaeus), Exelastis atomosa (Walshinghan), Melanagromyza obtusa (Malloch) and $S$. litura in Tamil Nadu responsible for considerable yield loss. Among these pests, leaf feeder, $S$. litura is a potential polyphagous pest which attack many crops such as cotton, groundnut, rice, tomato, 
tobacco, citrus, cocoa, pigeonpea, potato, rubber, castor, millets, sorghum, maize etc., in India and cause extensive economic damage (Vinod Kumari and Singh, 2009). Synthetic insecticides provide dramatic effect initially, and hence chemical control methods are still in use among farmers.

Earlier, conventional insecticides like malathion and hostathion (Sanjeev Kumar and Gill, 2010), chlorpyriphos (Kuttalam et al., 2008), synthetic pyrethroids and endosulfan alternatively with NSKE 4\% (Anon., 2009), and fenvalerate, methomyl, azinphosmethyl, carbaryl and pyrethrin/rotenone (Anon. 2012) were reported in management of pests on pigeonpea.

Application of insecticides against the insect pests is still considered as the first line of defense. However, increasing concern for the environmental pollution and the development of resistance on $S$. litura due to synthetic insecticides (Arms et al., 1992) has prompted the search for more effective and ecofriendly alternatives for pest control. Insecticides with different active compounds and modes of action are likely to be more effective than those have been so far used in controlling $S$. litura.

Biological insecticide molecule, spinetoram, is a multi-component tetracyclic macrolide which belongs to the new chemical class of spinosyn (Anonymous, 2006) and having unique mode of action (Group V insecticides) with an ecotoxicological profile similar to spinosad. Spinetoram has shown outstanding efficacy against major lepidopteran pests, western flower thrips and leaf miner (Dharne and Bagde, 2011), tomato caterpillar (Spodoptera litura Fabricius) (Muthukrishnan et al., 2013 a) and shoot and fruit borer (Leucinodes orbonalis Guenee) (Muthukrishnan et al., 2013 b). However, there are no reports on field effect of spinetoram $12 \mathrm{SC}$ against the $S$. litura on pigeonpea. The present study was therefore conducted to test the field efficacy of spinetoram $12 \mathrm{SC}$ on pigeonpea for two kharif seasons during 2012-13 and 2013-14.

\section{Materials and Methods}

Experiments were conducted at farmer's field at Jadhi Goundanpatti, Attur block, Dindigul District, Tamil Nadu, India. The experiments were laid out during September to March months of 2012 to 2013 and 2013 to 2014 kharif seasons in a randomized block design having plot size of $5 \times 5 \mathrm{~m}$. Pigeonpea (var. CO1) was raised as per recommended package of practices except insect pest management practices. Effect of seven insecticidal treatments comprising spinetoram 12 SC @ 45, 36 and $27 \mathrm{~g}$ a.i. ha ${ }^{-1}$ along with emamectin benzoate 5 SG @ 11 g a.i. ha ${ }^{-1}$, spinosad 45 SC @ $78 \mathrm{~g}$ a.i. ha ${ }^{-1}$ and monocrotophos 36 SL @ 500 g a.i. ha ${ }^{-1}$ was determined and each treatment was replicated thrice.

Three sprays of each insecticide were applied with the help of knapsack hand sprayer up to the point of runoff at fortnightly intervals starting from 50 per cent flower initiation. Observations on the larval population on number basis per plot from ten randomly selected plants were recorded at one day before and on 1, 3, 7 and 10 DAT after each spray. Grain yield was also taken after harvest and represented as yield $\mathrm{ha}^{-1}$. Two seasons data obtained were subjected to analysis of variance (ANOVA) after square root transformation of data as per the procedure suggested by Gomez and Gomez (1984) and original values are given in Table 1. The observations on phytotoxicity symptoms (leaf injury, wilting, vein clearing, necrosis, epinasty and hyponasty) were recorded on 7 DAT after each spray by using visual scoring system. 


\section{Results and Discussion}

Field evaluation of spinetoram $12 \mathrm{SC}$ against $S$. litura on pigeonpea

S. litura larval population varied from 4.1 to 5.3 per plant during first season before imposing treatments (Table 1) and crossed the economic threshold level (ETL). Mean larval population per plant ranged from 1.9 to 8.5 due to various treatments. Spinetoram $12 \mathrm{SC}$ 45 and 45 a.i./ha were on par and significantly superior in minimizing the population to 1.9 and 2.1 larvae per plant along with 77.6 and 75.0 per cent reduction respectively when compared to 8.5 larvae per plant of untreated plot.

Spinosad 45 SC $78 \mathrm{~g}$ a.i./ha, spinetoram 12 SC $27 \mathrm{~g}$ a.i./ha and emamectin benzoate $5 \mathrm{SG}$ at $11 \mathrm{~g}$ a.i./ha were the next best treatments, resulted in population of $2.3,2.6$ and 3.0 larvae per plant and registered 72.0, 69.0 and 64.0 per cent reduction respectively. Monocrotophos $36 \mathrm{SL}$ at $500 \mathrm{~g}$ a.i./ha was the least effective, which achieved only 57.6 per cent reduction with 3.6 larvae per plant.

Data pertaining to larval population of $S$. litura during second season for $1,3,7$ and 10 DAT after three sprays are presented in Table 1. Mean data revealed that number of larvae ranged from 1.6 to 10.3 larvae per plant due to treatments. Spinetoram 12 SC 45 registered the lowest larval population of $1.6(84.4 \%$ reduction over control).

Spinetoram 12 SC $36 \mathrm{~g}$ a.i./ha, spinosad 45 SC $78 \mathrm{~g}$ a.i./ha and Spinetoram 12 SC $27 \mathrm{~g}$ a.i./ha were significantly superior with 1.9 (81.5\% reduction over control), 2.0 (80.5\% reduction over control) and 2.1 per plant, respectively. Emamectin benzoate $5 \mathrm{SG}$ at 11 $\mathrm{g}$ a.i./ha also contributed moderate reduction in the larval population (2.7 larvae/plant with $73.7 \%$ reduction over control).
Monocrotophos $36 \mathrm{SL}$ at $500 \mathrm{~g}$ a.i./ha however registered higher larval population 3.9 larvae per plant with 62.1 per cent reduction over control. The present result are in corroboration with the findings of Sunilkumar et al., (2012) spinetoram 12 SC at $60 \mathrm{~g} \mathrm{a.i} / \mathrm{ha}$ was highly effective in checking the larval population of $S$. litura during both the years in soybean. The most effective insecticides for army worm (Spodopteraspp) control were spinetoram, spinosad and indoxacarb; the next most effective insecticides were novaluron and metaflumizone; and least effective were pyridalyl (Dakshina Seal et al., 2007). Cook et al., (2004) also reported that spinosad, indoxacarb and pyridalyl significantly reduced beet armyworm (S. exigua) compared to the control. Similar results of effectiveness of spinosad against $S$. exigua in cotton have been documented by Halcomb et al., (1998). Naiket al., (2008) who found that spinosad 0.015 per cent individually and combination with novaluron was most effective in reducing shoot infestation.

\section{Effect of spinetoram $12 \mathrm{SC}$ on grain yield}

Data on marketable pigeonpea grain yield ranged from 23.5 to $11.8 \mathrm{q} / \mathrm{ha}$ in first season experiment respectively due to all treatments. There was significant difference due to spinetoram 12 SC applications. Highest grain yield was recorded due to spinetoram $12 \mathrm{SC}$ $45 \mathrm{~g}$ a.i./ha $(23.5 \mathrm{q} / \mathrm{ha})$ and was followed by spinetoram 12 SC $36 \mathrm{~g}$ a.i./ha (22.3 q/ha).

Spinosad 45 SC 78 g a.i./ha, spinetoram 12 SC $27 \mathrm{~g}$ a.i./ha and emamectin benzoate $5 \mathrm{SG}$ at $11 \mathrm{~g}$ a.i./ha were the next best treatments, which contributed moderate yield of 19.4, 18.3 and $15.8 \mathrm{q} / \mathrm{ha}$ respectively. However, monocrotophos $36 \mathrm{SL}$ at $500 \mathrm{~g}$ a.i./ha registered lower fruit yield of $14.6 \mathrm{q} / \mathrm{ha}$ compared to untreated plot which recorded $11.8 \mathrm{q} / \mathrm{ha}$ grain yield. 
Table.1 Effect of spinetoram 12 SC against S. litura on pigeonpea (2012-2013 and 2013 -2014 seasons)

\begin{tabular}{|c|c|c|c|c|c|c|c|c|}
\hline \multirow[b]{3}{*}{ Treatments and doses (g a.i. /ha) } & \multicolumn{8}{|c|}{ Number of larvae/plant on days after treatment } \\
\hline & \multicolumn{4}{|c|}{ I season (Sep 2012 - Mar 2013) } & \multicolumn{4}{|c|}{ II season (Sep 2013 - Mar 2014) } \\
\hline & Pre count & $\begin{array}{c}\text { Over } \\
\text { all } \\
\text { Mean }\end{array}$ & $\begin{array}{c}\text { Per cent } \\
\text { reduction } \\
\text { over control }\end{array}$ & $\begin{array}{l}\text { Yield } \\
\text { (t/ha) }\end{array}$ & Pre count & $\begin{array}{c}\text { Over all } \\
\text { Mean }\end{array}$ & $\begin{array}{c}\text { Per cent } \\
\text { reduction } \\
\text { over control }\end{array}$ & $\begin{array}{l}\text { Yield } \\
\text { (t/ha) }\end{array}$ \\
\hline Spinetoram 12 SC 27 g a.i./ha & 4.1 & $2.6^{\mathrm{c}}$ & 69.0 & $18.3^{\mathrm{d}}$ & 6.5 & $2.1^{\mathrm{b}}$ & 79.6 & $14.5^{\mathrm{d}}$ \\
\hline Spinetoram 12 SC $36 \mathrm{~g}$ a.i./ha & 4.7 & $2.1^{\mathrm{ab}}$ & 75.0 & $22.3^{\mathrm{b}}$ & 6.2 & $1.9^{\mathrm{b}}$ & 81.5 & $19.2^{b}$ \\
\hline Spinetoram 12 SC 45 g a.i./ha & 4.2 & $1.9^{\mathrm{a}}$ & 77.6 & $23.5^{\mathrm{c}}$ & 5.8 & $1.6^{\mathrm{a}}$ & 84.4 & $21.1^{\mathrm{a}}$ \\
\hline Emamectin benzoate 5 SG 11 g a.i./ha & 4.5 & $3.0^{\mathrm{d}}$ & 64.0 & $15.8^{\mathrm{e}}$ & 6.4 & $2.7^{\mathrm{c}}$ & 73.7 & $13.8^{\mathrm{d}}$ \\
\hline Spinosad 45 SC 78 g a.i./ha & 4.7 & $2.3^{\mathrm{b}}$ & 72.0 & $19.4^{\mathrm{c}}$ & 5.9 & $2.0^{\mathrm{b}}$ & 80.5 & $17.0^{\mathrm{c}}$ \\
\hline Monocrotophos 36 SL 500 g a.i./ha & 5.3 & $3.6^{\mathrm{e}}$ & 57.6 & $14.6^{\mathrm{f}}$ & 6.1 & $3.9^{\mathrm{d}}$ & 62.1 & $12.8^{\mathrm{e}}$ \\
\hline Untreated check & 5.1 & $8.5^{\mathrm{f}}$ & & $11.8^{\mathrm{g}}$ & 6.6 & $10.3^{\mathrm{e}}$ & & $9.8^{\mathrm{f}}$ \\
\hline CD $(0.05 \%)$ & - & 0.27 & & 0.77 & - & 0.27 & & 0.83 \\
\hline SEd & - & 0.12 & & 0.35 & - & 0.12 & & 0.38 \\
\hline
\end{tabular}

Data are mean values of three replications. Figures were transformed by arc sine transformation and the original values are given Means within columns lacking common lower case superscript are significantly different $(\mathrm{P}<0.05)$ 
Pigeonpea grain yield ranged from 9.80 to $21.1 \mathrm{q} / \mathrm{ha}$ during second season due to treatments. There was significant difference due to spinetoram 12 SC applications. Highest grain yield was recorded due to spinetoram 12 SC $45 \mathrm{~g}$ a.i/ha $(21.1 \mathrm{q} / \mathrm{ha})$ and was followed by spinetoram $12 \mathrm{SC} 36 \mathrm{~g}$ a.i/ha (19.20 q/ha) and spinosad $45 \mathrm{SC} 78 \mathrm{~g}$ a.i./ha. Emamectin benzoate $5 \mathrm{SG}$ at $11 \mathrm{~g}$ a.i/ha which was on par with spinetoram 12 SC $27 \mathrm{~g}$ a.i/ha contributed higher yield of 13.8 and $14.5 \mathrm{q} / \mathrm{ha}$ respectively. However, monocrotophos $36 \mathrm{SL}$ at $500 \mathrm{~g} \mathrm{a}$.i/ha registered moderate grain yield of $23.4 \mathrm{q} / \mathrm{ha}$ compared to untreated plot which recorded $9.8 \mathrm{q} / \mathrm{ha}$ grain yield.

Similar observation by Sreekanth and Seshamahalakshmi (2012), who reported that highest grain yield was recorded in spinosad $45 \mathrm{SC} 73 \mathrm{~g}$ a.i/ha treated plots $(831.0 \mathrm{~kg} / \mathrm{ha})$, followed by Bt.1@1.5 kg/ha $(743.1 \mathrm{~kg} / \mathrm{ha})$ and B. bassiana SC formulation @ $300 \mathrm{mg} / 1$ (694.4 kg/ha) with 104.0, 82.4 and 70.7 per cent yield increase over control respectively as against the minimum yield of $407.4 \mathrm{~kg} / \mathrm{ha}$ in the untreated check. Muthukrishnan et al., (2013 b), spinetoram was also very effective against shoot and fruit damage due to $L$. orbonalis, safe to natural enemies and enhances the fruit yield of brinjal. There was no phytotoxicity symptoms like leaf injury, wilting, vein clearing, necrosis, epinasty and hyponasty recorded on $7^{\text {th }}$ DAT after each spray due to any doses of spinetoram 12 SC on pigeonpea plants.

\section{Acknowledgement}

The authors express sincere thanks to Dow Agro Science India Pvt. Ltd, Mumbai for providing financial help during the course of investigations. Authors are also thankful to Tamil Nadu Agricultural University, Coimbatore and Agricultural College and Research Institute, Madurai for granting permission to publish the results

\section{References}

Anonymous, 2006. Dow Crop Science Spinetoram. Technical Bulletin, 1-4.

Anonymous, 2009. Indian horticulture data base NHB. Ministry of Agriculture, Govt. of India, 154-61.

Anonymous, 2012. Dow Crop Science Spinetoram. Technical Bulletin 1-11.

Anonymous, 2013. India stat. (http://www.indiastat.com).

Armes, N.J, Jadhav, D. R. and Desouza, K.R. 1992. A survey of insecticide resistance in Helicoverpa armigera in the Indian sub-continent. Bulletin of Entomological Research86: 499-514.

Cook, D. R, Leonard, B. R. and Gore, J. 2004. Field and laboratory performance of novel insecticides against armyworms (Lepidoptera: Noctuidae). Florida Entomologist., 87(4): 433-439.

Dakshina Seal, R, David Schuster, J. and Klassen, W. 2007. Comparative effectiveness of new insecticides in controlling armyworms (Lepidoptera: Noctuidae) and leafminers (Diptera: Agromyzidae) on tomato. Proc. Fla. State Hort. Soc. 120: 170-177.

Dharne, P.K. and Bagde, A.S. 2011. Bio efficacy of novel insecticide, spinetoram $12 \mathrm{SC}(11.7 \mathrm{w} / \mathrm{w})$ against thrips, Scirtothrips dorsalis Hood and fruit borer, Helicoverpa armigera $\mathrm{HB}$ in chilli. Pestology 35(3): 23-26.

Gomez, K.A. and Gomez, A.A. 1984. Statistical procedures for Agricultural Research.A Wiley International Science Publication, John Wiley and Sons, New Delhi. 680p.

Halcomb, J.L, Benedict, J.H. and Correa. J.C. 1998. A field study to evaluate the efficacy of selected insecticides against beetworm on transgenic cotton. In "Arthropod Management Tests", Entomol. Soc. Amer. Lanham, MD. p 229-230. 
Kuttalam, S., Vinothkumar, B, Kumaran, N. and Boomathi, N. 2008. Evaluation of bio efficacy of flubendiamide $480 \mathrm{SC}$ against fruit borer Helicoverpa armigerain tomato. Pestology. 32(3): 13-16.

Muthukrishnan, N, Visnupriya, M, Babyrani, $\mathrm{M}$ and Muthuiah, C. 2013b. In-vivo and Field Evaluation of Spinetoram 12 SC against Spodoptera litura Fabricius on Tomato. Madras Agric. J., 100(4-6): 601-604.

Muthukrishnan, N, Visnupriya, M., Babyrani, $\mathrm{M}$ and Muthuiah, C. 2013a. Persistence Toxicity and Field Evaluation of Spinetoram 12 SC against Shoot and Fruit borer, Leucinodes orbonalis Guenee in Brinjal. Madras Agric. J., 100(4-6): 605-608.

Naik, V, Babu, C, Arjuna, R.P, Krishnayya, P.V and Chalam, M.S.V. 2008. Seasonal incidence and management of Bemisiatabaci and Amrasca biguttula biguttula of brinjal. Ann. Pl. Protec. Sci., 17(2): 9-13.
Sanjeev Kumar, A and Gill, C.K. 2010. Incidence of tomato leaf curl virus in relation to whitefly, Bemisia tabaci (Gennadius) population in different insecticidal treatments on tomato crop. J. Insect Sci23(3): 327-331.

Sreekanth, $M$ and Seshamahalakshmi, M. 2012. Studies on relative toxicity of biopesticides to Helicoverpa armigera (Hubner) and Maruca vitrata (Geyer) on pigeonpea (Cajanus cajan L.). Biopesticides against pigeon pea pest. $J$. Biopest., 5(2): 191-195.

Sunilkumar, N.M, Shivanand, T.W, Kukanur, V.S, Sunil, K, Naveen, K and Patil, B. 2012. Evaluation of spinetoram 12 SC against Spodoptera litura (Fab.) in soybean.Bioinfolet.9 (3): 378-381.

Vinod Kumari, and Singh, N.P. 2009. Spodoptera litura nuclear polyhedrosis virus (NPV-S) as a component in Integrated Pest Management (IPM) of Spodoptera litura (Fab.) on cabbage. J. Biopesticides, 2(1) 84-86.

\section{How to cite this article:}

Sanjeevi Kumar and Muthukrishnan. 2017. Field Evaluation of Spinetoram 12 SC against Spodoptera litura Fabricius on Pigeonpea. Int.J.Curr.Microbiol.App.Sci. 6(11): 2818-2823. doi: https://doi.org/10.20546/ijcmas.2017.611.332 